\title{
Correction to: Experimental investigation on the reversibility of concrete creep under repeating loads
}

\author{
Marija Docevska (1D · Goran Markovski • Peter Mark
}

Published online: 6 July 2020

(C) The Author(s) 2020

\section{Correction to:}

Materials and Structures (2019) 52:83

https://doi.org/10.1617/s11527-019-1384-3

The article "Experimental investigation on the reversibility of concrete creep under repeating loads", written by "Marija Docevska, Goran Markovski, Peter Mark", was originally published electronically on the publisher's Internet portal (currently SpringerLink) on 26 July 2019 without open access.

The copyright of the article changed in May 2020 to The Author(s) 2020 and the article is forthwith distributed under the terms of the Creative Commons Attribution 4.0 International License (http://creative commons.org/licenses/by/4.0/), which permits use,

The original article can be found online at https:// doi.org/10.1617/s11527-019-1384-3.

M. Docevska $(\varangle) \cdot$ G. Markovski

Faculty of Civil Engineering, Chair for Concrete and Timber Structures, Ss. Cyril and Methodius University, Blvd. Partizanski Odredi 24, 1000 Skopje, Republic of North Macedonia

e-mail: docevska@gf.ukim.edu.mk

G. Markovski

e-mail: markovski@gf.ukim.edu.mk

P. Mark

Institute of Concrete Structures, Ruhr University Bochum, Universitätsstraße 150, 44780 Bochum, Germany

e-mail: peter.mark@rub.de duplication, adaptation, distribution and reproduction in any medium or format, as long as you give appropriate credit to the original author(s) and the source, provide a link to the Creative Commons license and indicate if changes were made.

Open Access This article is distributed under the terms of the Creative Commons Attribution 4.0 International License (http://creativecommons.org/ licenses/by/4.0/), which permits unrestricted use, distribution, and reproduction in any medium, provided you give appropriate credit to the original author(s) and the source, provide a link to the Creative Commons license, and indicate if changes were made.

Publisher's Note Springer Nature remains neutral with regard to jurisdictional claims in published maps and institutional affiliations. 